\title{
Studies toward New Anti-Cancer Strategies Based on $\alpha$-Mannosidase Inhibition
}

\author{
Sandrine Gerber-Lemaire ${ }^{\#{ }^{\star}}$ and Lucienne Juillerat-Jeanneret ${ }^{\mathrm{b}}$
}

\#Werner Prize Winner 2010

\begin{abstract}
Changes in the glycosylation pattern of cellular glycoproteins constitute a hallmark in human cancer and influence tumor progression, suggesting that inhibitors of selected glycosidases may control cancer progression. Following the studies on swainsonine, a natural inhibitor of Golgi $\alpha$-mannosidase II, which highlighted the inhibition of cellular mannosidases as a potential innovative approach for the treatment of cancer, several dihydroxylated pyrrolidines and analogues were developed as new potent inhibitors of $\alpha$-mannosidases II able to induce antiproliferative effects in human cancer cells.
\end{abstract}

Keywords: Anti-cancer agents $\cdot$ Endothelial cells $\cdot$ Glioblastoma $\cdot \alpha$-Mannosidase inhibitors

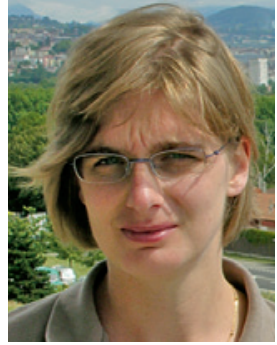

Sandrine Gerber-Lemaire was born in Paris in 1971. She studied chemistry at the Ecole Nationale Supérieure de Chimie de Paris in France, where she obtained a diploma of chemical engineer in 1993. The same year she obtained a DEA (Master degree) of organic chemistry at the University Pierre et Marie Curie (Paris VI, France). From 1993 to 1996 she did a PhD in organic chemistry under the supervision of Prof. Jean-Pierre Genêt at the Ecole Nationale Supérieure de Chimie de Paris. In 1996, she moved to University of Lausanne for a post-doctoral stay under the supervision of Prof. Pierre Vogel. In 1998, she was appointed Maître-Assistante at the Institute of Organic Chemistry in the University of Lausanne. In 2003 she was appointed adjointe scientifique

${ }^{*}$ Correspondence: MER Dr. S. Gerber-Lemaire ${ }^{a}$ Tel.: + 41216939372

Fax: + 41216939355

E-mail: Sandrine.Gerber@epfl.ch

alnstitute of Chemical Sciences and Engineering

Ecole Polytechnique Fédérale de Lausanne

Batochime

$\mathrm{CH}-1015$ Lausanne

Switzerland

bUniversity Institute of Pathology

CHUV

$\mathrm{CH}-1011$ Lausanne at the EPFL and since 2006 she is Maître d'Enseignement et de Recherche.

Since September 2007, Sandrine Gerber is deputy director of the Institute of Chemical Sciences and Engineering (ISIC).

In 2003, she obtained the habilitation to direct research from the University Pierre et Marie Curie (Paris VI, France). She was awarded the Prize Eugene Schueller in 1997, the Prize Dufour for prospective organic chemistry in 2005 and the Werner Prize 2010.

\section{Introduction}

The combined and ordered sequential action of glycosidases and glycosyltransferases in mammalian cell compartments leads to the addition of defined glycans to proteins and lipids. Altered glycosylation patterns, neoexpression, underexpression or overexpression of glycans are a hallmark of cancer. These changes are either found in the core or the terminal structures of the carbohydrates of glycoproteins. Affected proteins can be either cellular, cell-surface or secreted proteins, and glycosylation modifications frequently result in modified expression, metabolism, functions, properties, stability and/or cellular localization of glycoproteins in cancer cells, resulting in part in their uncontrolled growth and aggressive behavior. Therefore glycosylation pathways, and the glycosidases and glycosyltransferases of these pathways, represent potential innovative modalities for drug development in cancer therapies. Our group has thus been focus- ing on the design, synthesis and biological evaluation of pyrrolidine-based inhibitors of $\alpha$-mannosidases for the development of new anti-cancer agents.

\section{Glycosidases in Cancer}

Glycosylation as an additional level of regulation has been documented for human diseases, including cancer, and it has been realized that glycans expressed by diseased cells are either displayed at different levels, or with different structures than in normal cells. ${ }^{[1,2]}$ Therefore, glycosides and carbohydrate-dependent cellular pathways are important for the diagnosis, prognosis and progression of cancer, as well as representing potential new targets for therapeutic approaches. ${ }^{[3-8]}$ Changes in glycosylation pattern of glycoproteins is a common feature of human cancers, which influences tumor behavior, metastasis and immune surveillance. ${ }^{[9,10]}$ High levels of glycosidases, ${ }^{[1]}$ mostly active at the $\mathrm{C}(1)$ position of the sugar backbone, have been found in thyroid, gastric and colon carcinoma, ${ }^{[12-27]}$ which have been hypothesized to be linked to defective maturation in the Golgi network of lysosomal $\alpha$-glycosidase in colon cancer cells. ${ }^{[18]}$ Acid lysosomal glycosidases, including $\alpha$-sialidase, $\beta$-galactosidase, $\alpha$ - and $\beta$-mannosidases, and/ or cytosolic glycosidases are involved in protein catabolism, and the carbohydrate structure of their protein substrates may be an important factor in the half-lives of cellular glycoproteins. ${ }^{[28]}$ Increased expression of catabolic glycosidases has been demonstrated in cancer. ${ }^{[29]}$ Increased acidic 
$\beta$-galactosidase activity has been linked to drug-induced senescence of tumor cells, ${ }^{[30]}$ whereas high expression of $\beta$-glucosidase and $\beta$-galactosidase activities in cancer cells can also be useful to activate less toxic geldamycin-carbohydrate conjugates to active geldamycin in target tumor cells. ${ }^{[31]}$ Inhibitors of specific enzymes of the tumor cell glycosylation pathways may thus prove useful to control cancer progression, at different levels of regulation.

\section{3. $\alpha$-Mannosidases and their Inhibitors in Cancer}

\subsection{The Different Classes of Human $\alpha-M a n n o s i d a s e s$ and their Models}

In the field of cancer, $\alpha$-mannosidases and $\alpha$-glucosidases are the most promising potential targets for the development of inhibitors of cellular glycosidases. We have focused our efforts on the inhibition of $\alpha$-mannosidases. Two main classes of human $\alpha$-mannosidases involved in the processing of glycoproteins have been presently characterized:

$\alpha(1,2)$ Mannosidases I (EC 3.2.1.113) are localized in the endoplasmic reticulum, where their main functions seem to be related to the quality control and correct folding of newly synthesized glycoproteins. These enzymes specifically hydrolyse $\alpha(1,2)$ mannoside bonds of complex carbohydrate structures. They do not hydrolyse simple aryl- $\alpha$-mannosides and are inverting enzymes. ${ }^{[32]}$

The $\alpha$-mannosidases II can be separated by ion-exchange chromatography, sizeexclusion and affinity chromatography, and subcellular fractionation, ${ }^{[33]}$ into three groups: acidic/lysosomal (MAN2B1, EC 3.2.1.24), intermediate/Golgi (MAN2A1, EC 3.2.1.114) and neutral/cytosolic (MAN2C1/6A8). Human Golgi $\alpha$-mannosidase II is active at $\mathrm{pH} 5.5-6$, activated by $\mathrm{Co}^{2+}$ and inhibited by SW ( $\mathrm{IC}_{50} 20-50$ $\mathrm{nM}$ ) and has a molecular weight of $130 \mathrm{kD}$ (disulfide-linked homodimer, a short cytoplasmic, a trans membrane/luminal stem and a large catalytic domains). Human lysosomal $\alpha$-mannosidase $\mathrm{II}^{[34]}$ is active at $\mathrm{pH} 4-4.5$, activated by $\mathrm{Zn}^{2+}$, and the single chain precursor has a molecular weight of $110 \mathrm{kD}$, which is processed to three fragments of 70,42 and $15 \mathrm{kD}$. It is widely distributed and mutations of this enzyme result in the lysosomal storage disease $\alpha$ mannosidosis. Increased expression of this enzyme has been demonstrated in extracts of glioma correlated with malignancy. [35] Human cytosol $\alpha$-mannosidase II is active at neutral $\mathrm{pH}$, prefers $\mathrm{Co}^{2+}$ to $\mathrm{Zn}^{2+}$ and has been only recently cloned as the 6A8mab-reactive protein. Its molecular weight is $120 \mathrm{kD}$, and it is inhibited by swainsonine SW $(20 \mu \mathrm{M})$. Thus $\mathrm{SW}$ inhibits the lysosomal enzyme with less efficacy than the Golgi enzyme. Reverse transfection of cytosol $\alpha$-mannosidase resulted in decreased growth of human nasopharyngeal tumor cells and increased ConA binding in permeabilized fixed cells. ${ }^{[36]}$ These three $\alpha$-mannosidases II contain very similar molecular weight and sequences at their active sites and hydrolyze $\alpha(1,2), \alpha(1,3)$ and $\alpha(1,6)$ linkages using identical enzymatic mechanisms. Golgi $\alpha$-mannosidase II (GMII) has been the most studied of this class of enzymes and is responsible for the specific trimming of two mannose residues from the branched GlcNAc$\mathrm{Man}_{5} \mathrm{GlcNAc}_{2}$ intermediate in the cellular maturation pathway of glycoproteins (Fig. 1). GMII cleaves the linkage between the $\mathrm{C}(1)$ atom of $\mathrm{Man}_{6}$ and $\mathrm{Man}_{7}$, and, respectively, the $\mathrm{O}(3)$ and $\mathrm{O}(6)$ atom of the $\alpha 1,6$-linked mannosyl branch $\left(\mathrm{Man}_{4}\right)$ of GlcNAcMan $_{5}$ GlcNAc $_{2}$. Drosophila GMII (dGMII) displays $61 \%$ sequence identity with human GMII, comparable substrate specificity, kinetic properties and inhibitor sensitivity, ${ }^{[37,38]}$ and can be used as a valid model of the structural and functional features of the mammalian enzyme. [39-41] Another reliable model of the mammalian GMII is $\alpha$-mannosidase from jack bean. ${ }^{42]}$ Its amino acid sequence surrounding the catalytic nucleophile, identified as aspartic acid, reveals high sequence similarity with mammalian Golgi $\alpha$-mannosidase II.

\subsection{The Biological Effects of Swainsonine}

The alkaloid swainsonine (SW) was the first chemically synthesized inhibitor of $\alpha$-mannosidases II. SW mimics the binding of the transition-state analog and is a potent inhibitor of $\alpha$-mannosidases II with aryl- $\alpha$-mannosides as substrates. The effect of SW on different human cancer cell lines was evaluated. Treatment of human hepatoma cells with SW resulted in an accelerated secretion of hybrid forms of the glycoproteins transferrin, ceruloplasmin, $\alpha 2$-macroglobulin and $\alpha 1$-antitrypsin, whereas the secretion of non-glycoproteins was not affected. ${ }^{[43]}$ The transport of these hybrid glycoproteins through the Golgi apparatus was faster than the transport of normal glycoproteins. In in vivo experiments ${ }^{[44]}$ in mice injected with the B16-F10 murine melanoma cell line, melanoma cells incubated with SW prior to injection displayed a dose-dependent inhibition of lung colonization. Nevertheless the tumorigenic properties of B16-F10 cells were not affected by SW. In experimental murine cancer models, administration of SW in drinking water, before or after surgical excision of the primary tumor, inhibited by 95 and $88 \%$ the formation of spontaneous metastases to the liver and the lungs of the highly invasive M5076 murine reticulosarcoma or B16-F10 murine melanoma cells. ${ }^{[45]} \mathrm{SW}$ also enhanced the immune effector functions and decreased the toxicity of several anticancer agents. ${ }^{[46]}$ Phase I clinical trials of patients with advanced malignancies demonstrated that some patients showed a significant decrease of tumor mass when given SW.[47] The major side-effects observed with intravenous or oral administrations were pulmonary edema and neurological symptoms only for the oral study. In vitro $\mathrm{SW}$ increased the adhesion of bladder cancer cells to laminin, collagen IV and fibronectin, associ-

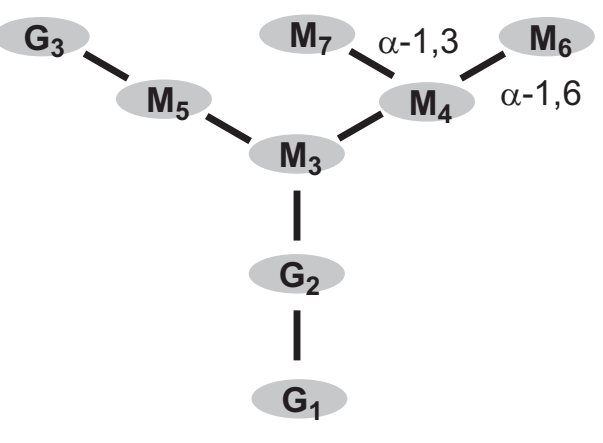<smiles>O[C@H]1CN2CCC[C@@H](O)[C@H]2[C@H]1O</smiles>

Swainsonine (SW, 1)

$\mathrm{IC}_{50}=0.4-0.1 \mu \mathrm{M}$ (jack bean)

$\mathrm{IC}_{50}=0.03 \mu \mathrm{M}(\mathrm{dGMII})$
Fig. 1.

Representation of the GlcNAcMan $_{5}-$ GlcNAc, substrate of dGMII (M = mannose and $\mathrm{G}=\mathrm{N}$-acetylglucosamine) and structure of swainsonine. 
ated to decreased migratory ability, ${ }^{[48]}$ but did not directly inhibit tumor cell growth. The undesired effects associated with the use of SW prompted us to develop new pyrrolidine-based inhibitors to achieve both high affinity toward $\alpha$-mannosidase II and anti-cancer activity with decreased side effects.

\section{Combinatorial Approach for the Discovery of new $\alpha$-Mannosidase Inhibitors}

The search for new $\alpha$-mannosidase inhibitors that might be used as anti-metastatic agents is an important field of investigation and some synthetic analogues of swainsonine (1) have also shown interesting properties.[49,50] Simple synthetic analogues such as dihydroxypyrrolidines substituted on the lateral side chain by an amino moiety might also be potent $\alpha$-mannosidase inhibitors and maybe offer better selectivity towards this enzyme. We hypothetized that $(2 R, 3 R, 4 S)$-2-(benzylamino)methyl-3,4-dihydroxypyrrolidine and analogues could mimic a transition or intermediate structure of the hydrolytic process in which the enzyme intervenes with two carboxylic groups and thus be good inhibitors of $\alpha$-mannosidases (Fig. 2).

As the search for new inhibitors generally implies the multi-step synthesis of a large number of derivatives and their individual testing, we developed a combinatorial approach which allows the generation of a variety of functionalized pyrrolidines at the same time as their evaluation as $\alpha$-mannosidase inhibitors (measurement performed on the jack bean enzyme). The method relies on the mixing of amine $\mathbf{2}$ with a panel of aldehydes in conditions used to detect glycosidase inhibition (aqueous solution, $1 \mathrm{mM}$ concentration). After $24 \mathrm{~h}$ incubation ( $\mathrm{K}>$ 4.2.10 $10^{-6}$, measured for imine formation in the presence of benzaldehyde), the enzyme and substrate are added to detect inhibitory activity of the so-formed imines (Scheme 1). With this methodology, we demonstrated, on the one hand, that these imines are valid models for the inhibitory

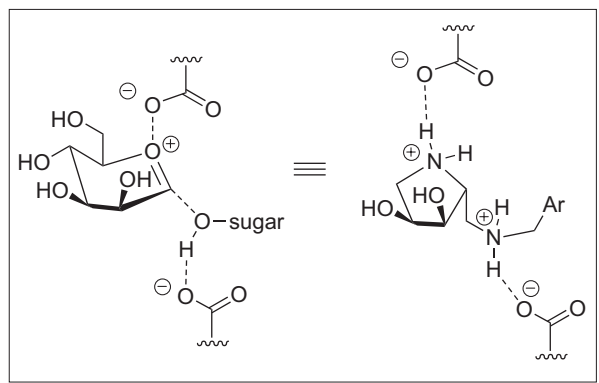

Fig. 2. Transition state of the enzymatic hydrolysis reaction of the glycoside.

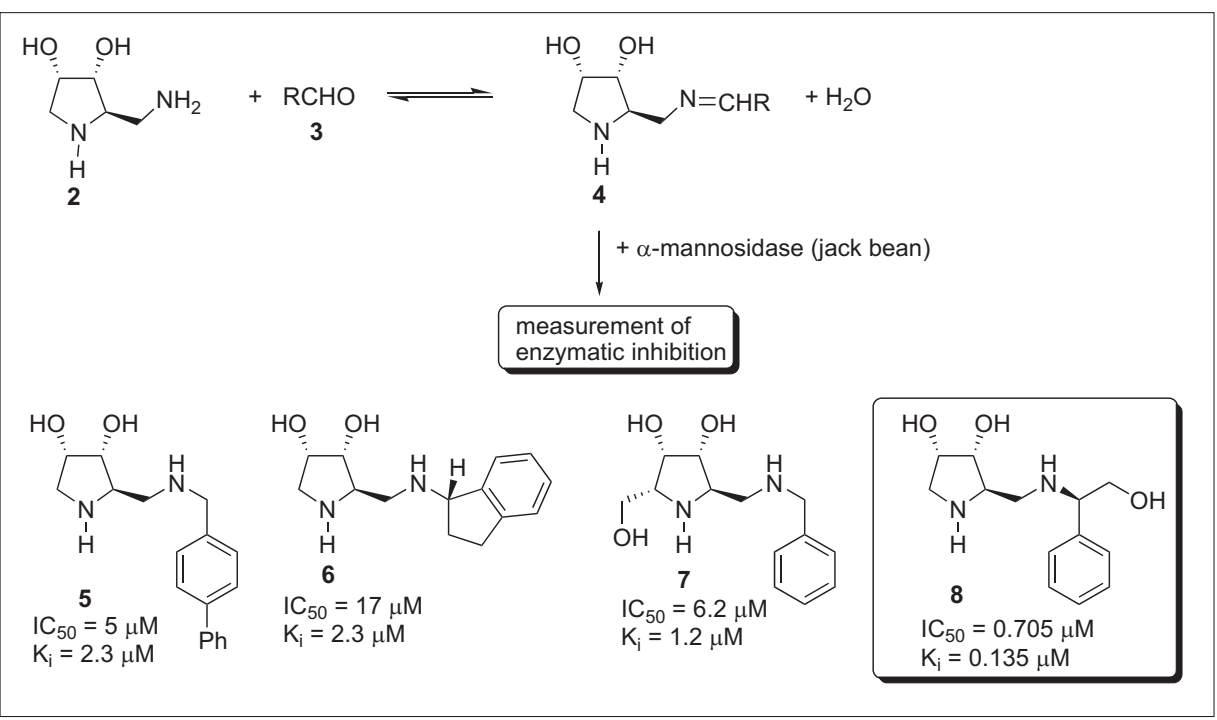

Scheme 1. Combinatorial approach for the identification of $\alpha$-mannosidase inhibitors

activities of the corresponding diamines and we screened, on the other hand, a panel of substituents that might provide affinity toward the targeted enzyme. ${ }^{[51]}$ While aliphatic aldehydes delivered poor inhibitors of $\alpha$-mannosidase from jack bean, several aromatic aldehydes provided potent inhibition toward this enzyme and thus allowed the synthesis of a new family of selective and competitive inhibitors based on a 2,3-dihydroxypyrroline scaffold. ${ }^{[52,53]}$ In particular, derivative 8 displayed an $\mathrm{IC}_{50}$ of $0.705 \mu \mathrm{M}$ and an inhibition constant of $0.135 \mu \mathrm{M}$.

Based on the lead inhibitor $\mathbf{8}$, further studies aimed at optimizing the structure to improve the affinity toward the targeted enzyme were initiated.

\section{Structure Optimization for the Discovery of High Affinity Inhibitors of Golgi $\alpha$-Mannosidase II}

Co-crystallization of Drosophila GMII with our first lead $\mathbf{8}$ allowed elucidation of its binding in the active site of the enzyme (Fig. 3, dGMII:8, GB1 name given by the Protein Data Bank). ${ }^{[54]}$ The hydroxyl moieties of the pyrrolidine ring make tight interactions with the active site zinc. Trp95 displays two types of pi interactions: the commonly seen stacked interaction with the five-membered ring as well as an unusual T-shaped interaction with the center of the aromatic ring. Nitrogen atoms and the terminal oxygen $(\mathrm{O}(9))$ provide several polar interactions. Interestingly and in contrast to other structures of dGMII:inhibitor complexes, there is no hydroxyl group occupying the space between Asp472 and Tyr727. We thus hypothesized that the introduction of polar substituents at the $\mathrm{C}(5)$ position of the pyrrolidine ring of compound $\mathbf{8}$ may induce additional interac- tions with these two residues of the enzyme active site. ${ }^{[55]}$

Replacement of the pyrrolidine moiety by a pyrrolidinone system was envisaged and led to the synthesis of derivatives 9 and 10. Whereas compound 9 displayed a significant decrease of the inhibitory potency toward $\alpha$-mannosidase for jack bean in comparison with the parent pyrrolidine

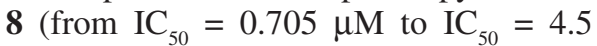
$\mu \mathrm{M})$, substitution of the lactam moiety by a methyl group induced a clear improvement of the inhibition potency toward this enzyme $\left(\mathrm{IC}_{50}=0.150 \mu \mathrm{M}\right.$ for $\mathbf{1 0} \mathrm{vs} \mathrm{IC}_{50}=$ $0.705 \mu \mathrm{M}$ for 8) (Fig. 4). Compound $\mathbf{1 0}$ appeared to be even more efficient than swainsonine. The inhibition of dGMII by pyrrolidine $\mathbf{8}$ was very modest, while transformation into a pyrrolidinone system led to a net improvement of the inhibitory activity. In particular, derivative $\mathbf{1 0}$ presented an $\mathrm{IC}_{50}$ of $0.5 \mu \mathrm{M}$ toward dGMII.

Analyses were then performed on the crystal structures of dGMII:10 (GB7, name given by the Protein Data Bank) to elucidate the difference of affinity toward the targeted enzyme between this inhibitor and the previous lead $\mathbf{8}$.

As previously seen for GB1 the phenyl rings make a T-shaped pi interaction with Trp95. The presence of the carbonyl group on the pyrrolidine ring in GB7 allows the formation of new hydrogen bonds between the carbonyl oxygen and both Asp472 and Tyr727 (Fig. 5A and 5B). The presence of the ketone moiety enforces a planarity in that section of the pyrrolidine ring, and the bound conformation of the pyrrolidine ring is clearly different in the two structures. Overlaying the structure of bound GB7 with the potent inhibitor swainsonine shows that the positions of the hydroxyl groups (or carbonyl group in GB7) are very similar (Fig. 5C). The interaction 

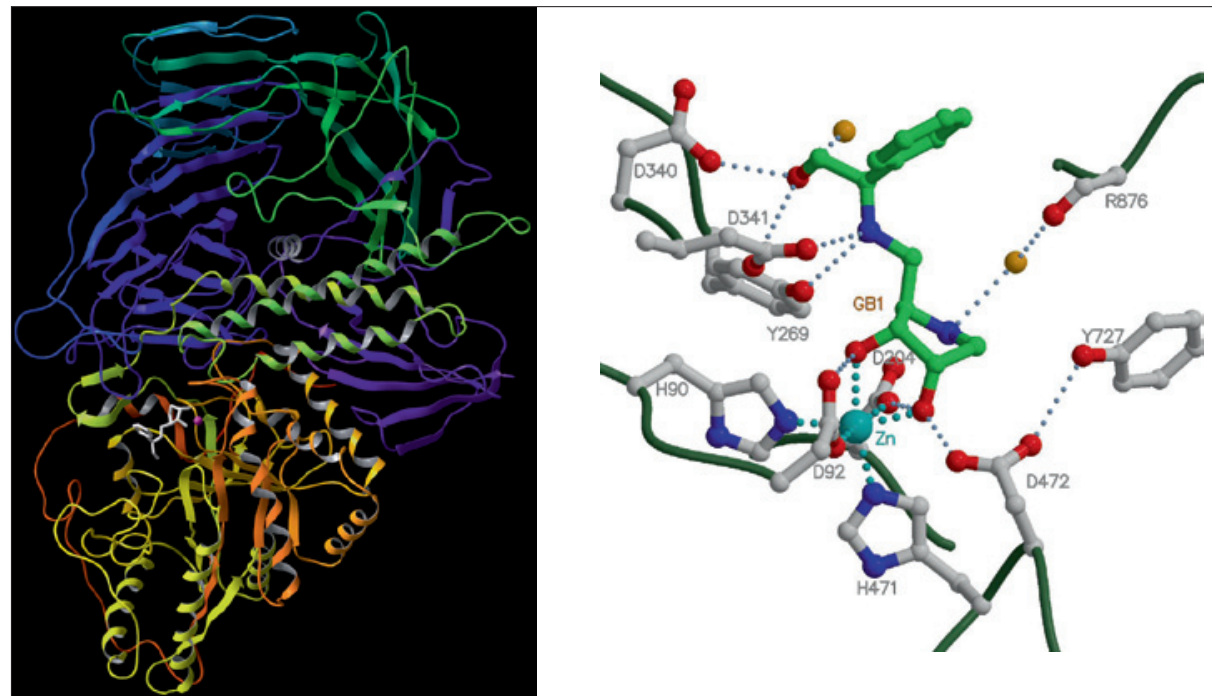

Fig. 3. Crystal structure of $\mathbf{8}$ complexed to dGMII. Stereoview of the interactions of $\mathbf{8}$ (GB1) with residues in the active site of dGMII. Interactions closer than $3.5 \AA$ are indicated. The interactions with zinc are indicated in cyan. Water molecules appear as orange balls. Zinc appears as a cyan ball.

\begin{tabular}{|c|c|c|c|}
\hline \multirow{2}{*}{} & Compound & $\begin{array}{c}\text { a-mannosidase } \\
\text { (jack bean) }\end{array}$ & dGMII \\
\hline $\mathrm{SW}(\mathbf{1})$ & $\begin{array}{c}\mathrm{IC}_{50}=0.398 \mu \mathrm{M} \\
\mathrm{K}_{\mathrm{i}}=0.155 \mu \mathrm{M}(\mathrm{C})\end{array}$ & $\mathrm{IC}_{50}=0.03 \mu \mathrm{M}$ \\
\cline { 2 - 4 } & $\mathbf{8}$ & $\begin{array}{c}\mathrm{IC}_{50}=0.705 \mu \mathrm{M} \\
\mathrm{K}_{\mathrm{i}}=0.135 \mu \mathrm{M}(\mathrm{C})\end{array}$ & $\mathrm{IC}_{50}=80 \mu \mathrm{M}$ \\
\cline { 2 - 4 } & $\mathbf{9}$ & $\begin{array}{c}\mathrm{IC}_{50}=4.5 \mu \mathrm{M} \\
\mathrm{K}_{\mathrm{i}}=4.0 \mu \mathrm{M}(\mathrm{C})\end{array}$ & $\mathrm{IC}_{50}=7 \mu \mathrm{M}$ \\
\hline $\mathbf{1 0}, \mathrm{R}=\mathrm{R}=\mathrm{Me}$ & $\begin{array}{c}\mathrm{IC}_{50}=0.150 \mu \mathrm{M} \\
\mathrm{K}_{\mathrm{i}}=0.206 \mu \mathrm{M}(\mathrm{C})\end{array}$ & $\mathrm{IC}_{50}=0.50 \mu \mathrm{M}$ \\
\hline
\end{tabular}

Fig. 4. Inhibitory activity of pyrrolidine and pyrrolidinone derivatives toward $\alpha$-mannosidases. $\mathrm{C}=$ Competitive inhibitor.

distances between these portions of the inhibitors and the portions of the dGMII to which they bind (Zinc, Asp92, Asp204, Asp472, Tyr727) are all very comparable.
The N-methyl group in GB7 is close to the position of the $\mathrm{C}(6)$ group of swainsonine. The N-methyl group is pointing towards a hydrophobic pocket in the active site composed of Phe206, Trp415 and Tyr727. This extra hydrophobic interaction formed by the methyl group with the hydrophobic pocket may be responsible for the increased efficacy of derivative $\mathbf{1 0}$ compared to 9 .

\section{Evaluation of $\alpha$-Mannosidase Inhibitors as Growth Inhibitors of Cancer Cells}

\subsection{Inhibition of $\alpha-$ Mannosidases Extracted from Human Cells}

For the biological evaluation of our inhibitors, glioblastoma (LNZ308 and LN18 cell lines) were targeted as these tumors are associated with a high proliferative and invasive potential, multiple resistance toward conventional chemotherapeutic agents and poor prognosis. As the angiogenic endothelial cells associated with cancer may also be targets of therapeutic intervention, human brain-derived endothelial cells (HCEC) were also investigated as model for angiogenic endothelial cells associated with glioblastoma.

The inhibition of $\alpha$-mannosidase II activity extracted from human glioblastoma and endothelial cells by our inhibitors and swainsonine was measured at pH 5 (Table 1). ${ }^{[55]}$ Derivative 8 showed a moderate inhibitory potency on $\alpha$-mannosidases from all cell extracts $\left(\mathrm{IC}_{50}=50 \mu \mathrm{M}\right)$. Introduction of an oxo moiety at the $\mathrm{C}(5)$ position of the five-membered ring did not change the activity significantly. However, the $\mathrm{N}$-methyl pyrrolidinone compound (10) displayed potent inhibitory activity on $\alpha$ mannosidases from LNZ308, LN18 and HCEC extracts $\left(\mathrm{IC}_{50}=500 \mathrm{nM}, 2.0 \mu \mathrm{M}\right.$ and $500 \mathrm{nM}$, respectively), although lower than swainsonine. This result is in agreement with the observations made on the dGMII enzyme, highlighting the reliability of this model for the corresponding human enzyme. Interestingly, the inhibition of $\alpha$ -
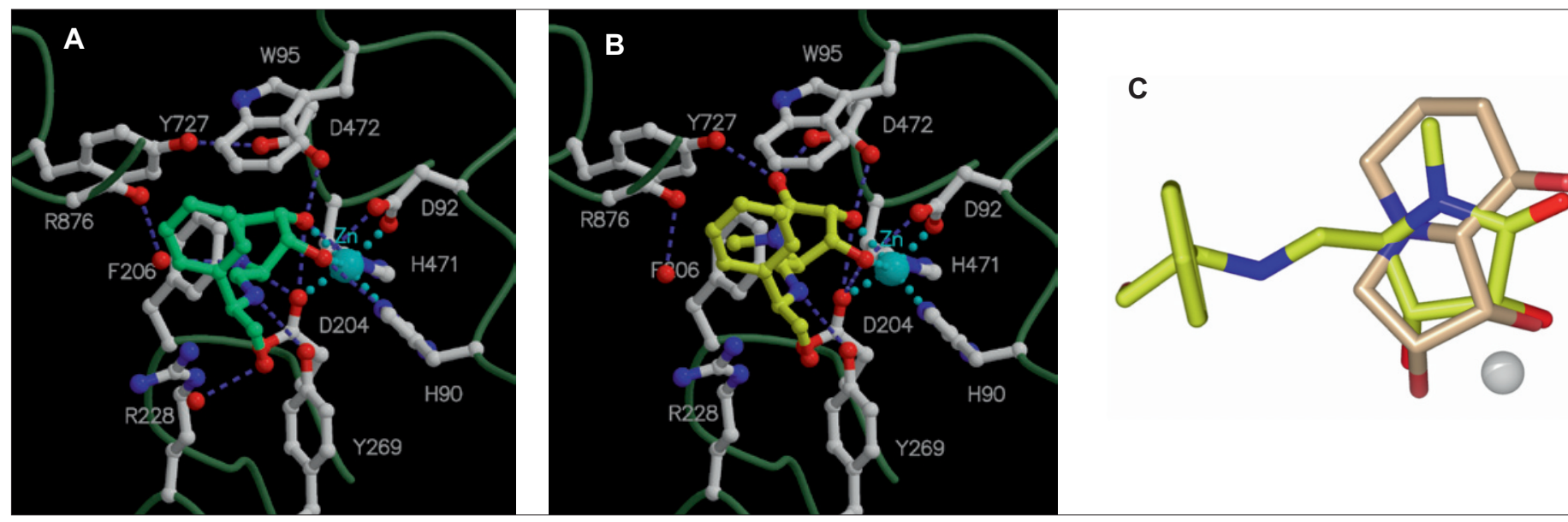

Fig. 5. Comparison of pyrrolidine analogs in the active site of dGMII. A illustrates the structure GB1, B the GB7 structure and C the superimposition of $\mathbf{G B 7}$ with swainsonine. Zinc appears as cyan, (A, B) or grey balls (C). 
mannosidases II by $\mathbf{1 0}$ was more efficient in LNZ308 and HCEC cells than in LN18 cells, whereas inhibition by swainsonine was similar in all three cell types.

\subsection{Growth Inhibition of Human Glioblastoma Cells and Fibroblasts}

The ability of $\alpha$-mannosidase inhibitors to induce inhibition of the growth of human glioblastoma was investigated. ${ }^{[56]}$ First, evaluation of swainsonine, $\mathbf{8}$, and $\mathbf{1 0}$ on glioblastoma cells revealed that none of these potent $\alpha$-mannosidase inhibitors were able to diminish cancer cell growth. As the hydrophilic character of these molecules may hinder their transport across cell membranes, a series of more lipophylic derivatives (esters, ethers and amides) of $\mathbf{8}$ was synthesized. ${ }^{[57-59]}$ Among these compounds, the 4-bromobenzoate derivative $\mathbf{1 1}$ demonstrated a concentration-dependent inhibition of growth with almost complete inhibition at $300 \mu \mathrm{M}$ (Fig. 6). The same transformation on pyrrolidinone $\mathbf{1 0}$ also led to an inhibitor of glioblastoma cells growth (12). A dose-response evaluation (from $300 \mu \mathrm{M}$ to $100 \mu \mathrm{M}, 48 \mathrm{~h}$ of exposure to 11 and 12) of the anti-proliferative effects on glioblastoma cells (LN18 and LNZ308) allowed determination of $\mathrm{IC}_{50}$ values between 100 and $175 \mu \mathrm{M}$ for these two compounds. Further experiments demonstrated that these derivatives act initially by inhibiting DNA synthesis, then the rate of protein synthesis decreases, resulting in diminished cell survival, whereas swainsonine was not active under the same conditions. These derivatives were also active on melanoma cells (data not shown).

These results indicate that the transport across cell membranes through the ester functionality and their intracellular trapping following esterase-promoted hydrolysis is an important factor for their efficacy in human cells.

Furthermore, activity of derivatives $\mathbf{1 1}$ and $\mathbf{1 2}$ on non-tumoral fibroblasts was evaluated (Fig. 7). Interestingly, while pyrrolidine $\mathbf{1 1}$ showed only moderate selectivity as $60 \%$ growth inhibition was observed at $300 \mu \mathrm{M}$ after $48 \mathrm{~h}$ of incubation, the pyrrolidinone analogue $\mathbf{1 2}$ was highly selective. Almost no growth inhibition could be detected after $48 \mathrm{~h}$ of incubation with both fibroblast types even at high concentration.

The improved selectivity of $\mathbf{1 2}$ versus 11 for the growth inhibition of tumor-associated cells versus healthy human cells correlated with the increased inhibitory ability of $\mathbf{1 2}$ versus $\mathbf{1 1}$ on dGMII and human $\alpha$-mannosidases II. ${ }^{[55]}$

\section{Conclusions}

Glycosides and carbohydrate-dependent cellular pathways are important for

Table 1. Inhibition by SW and compounds 8-10 of $\alpha$-mannosidase activity extracted from human glioblastoma (LN18 and LNZ308) and endothelial (HCEC) cells at pH 5.0.

\begin{tabular}{|c|c|c|c|}
\hline Compound & LNZ308, IC ${ }_{50}=$ & $\mathrm{LN} 18, \mathrm{IC}_{50}=$ & $\mathrm{HCEC}, \mathrm{IC}_{50}=$ \\
\hline SW, 1 & $20 \mathrm{nM}$ & $50 \mathrm{nM}$ & 10 nM \\
\hline 8 & $50 \mu \mathrm{M}$ & $50 \mu \mathrm{M}$ & $25 \mu \mathrm{M}$ \\
\hline 9 & $50 \mu \mathrm{M}$ & $350 \mu \mathrm{M}$ & $75 \mu \mathrm{M}$ \\
\hline 10 & $500 \mathrm{nM}$ & $2.0 \mu \mathrm{M}$ & $500 \mathrm{nM}$ \\
\hline
\end{tabular}

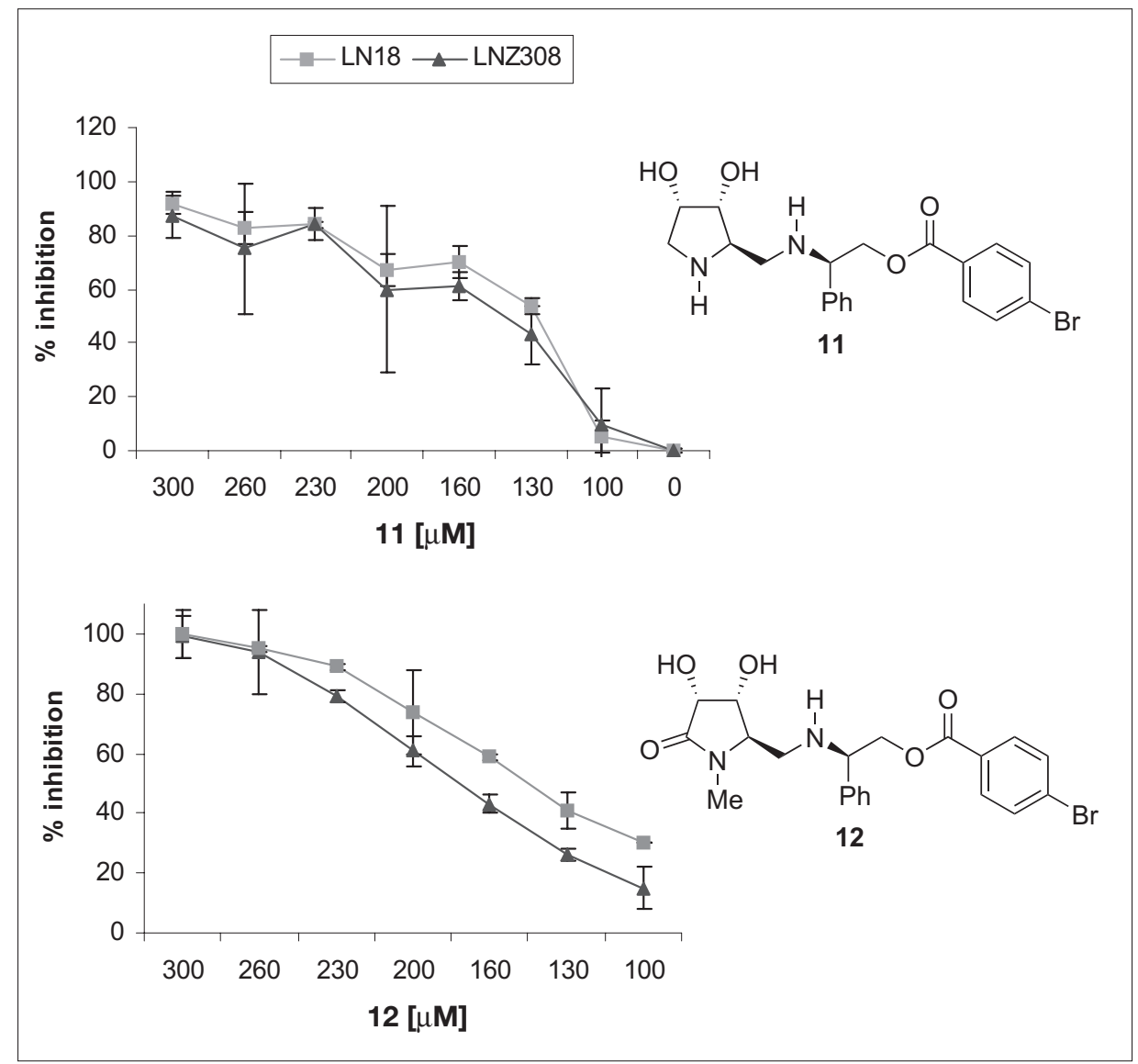

Fig. 6. Growth inhibition of human glioblastoma cells by $\mathbf{1 1}$ and 12. Human cells were exposed for $48 \mathrm{~h}$ to increasing concentrations of 11 and 12, then the MTT assay was performed for the last $2 \mathrm{~h}$ and the percent of growth inhibition was calculated as ratio of MTT reduction of treated to untreated cells (means \pm SD triplicate wells of one representative experiment out of three).

the diagnosis, prognosis and progression of cancer, as well as representing potential new targets for therapeutic intervention. [60] The information obtained until now indicates that the target glycosidases are of ubiquitous expression in normal cell as well as in tumor cell glycosylation processes. The differences may reside in the expression levels, or the cell localization of these enzymes. Unlike proteins and nucleic acids, glycosylation pathways as drug targets have remained relatively little studied until recently. However, in view of the importance of carbohydrates in fundamental cellular processes, therapeutic strategies will necessitate that drugs either are selective for defined cells, or are able to modulate rather than ablate defined glycosylation pathways. The pyr- rolidinone derivatives developed in our laboratory constitute new promising scaffolds for the investigation of future therapeutic drugs as anticancer and antiangiogenic agents. Further studies will include the design of cells-targeting conjugates in order to improve cell selectivity and reduce collateral damages generally encountered with chemotherapeutics.

Received: June 2, 2010

[1] J. W. Dennis, M. Granovski, C. E. Warren, BioEssays 1999, 21, 412.

[2] Y. Ito, S. Hagihara, I. Matsuo, K. Totani, Curr. Op. Structs. Biol. 2005, 15, 481.

[3] F. T. Liu, G. A. Rabinovich, Nat. Rev., Cancer 2005, 5, 29.

[4] M. A. Hollingsworth, B. J. Swanson, Nat. Rev., Cancer 2004, 4, 45. 


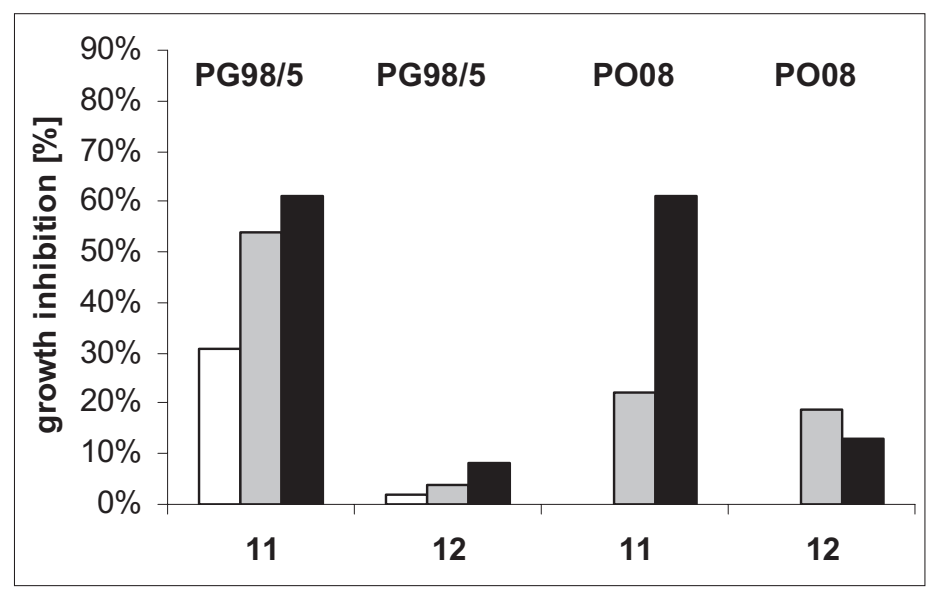

Fig. 7. Growth inhibition of human primary dermal fibroblasts (PG98/5) and human pulmonary fibroblasts (PO08) by $\mathbf{1 1}$ and 12. Human cells were exposed for $48 \mathrm{~h}$ to increasing concentrations of 11 and 12 , then the MTT assay was performed for the last $2 \mathrm{~h}$ and the percent of growth inhibition was calculated as ratio of MTT reduction of treated to untreated cells (means \pm SD triplicate wells of one representative experiment out of three). $\square: 100 \mu \mathrm{M}, \mathbf{\square}: 200 \mu \mathrm{M}, \mathbf{\square}: 300 \mu \mathrm{M}$.

[5] M. M. Fuster, J. D. Esko, Nat. Rev., Cancer $2005,5,526$.

[6] D. H. Dube, C. R. Bertozzi, Nat. Rev., Drug Disc. 2005, 4, 477 .

[7] R. A. Dwek, T. D. Butters, F. M. Platt, N. Zitzmann, Nat. Rev., Drug Disc. 2002, 1, 65.

[8] T. F. Scanlin, M. C. Glick, Glycoconjugate J. 2000, 17, 617 .

[9] P. Parham, Trends Biochem. Sci. 1996, 21, 427.

[10] P. M. Rudd, M. R. Wormald, R. L. Stanfield, M. Huang, N. Mattsson, J. A. Speir, J. A DiGennaro, J. S. Fetrow, R. A. Dwek, I. A Wilson J. Mol. Biol. 1999, 293, 351.

[11] B. Henrissat, Biochem. Soc. Trans. 1998, 26, 153.

[12] R. J. Bernacki, M. J. Niedbala, W. Korytnyk, Cancer Meta. Rev. 1985, 4, 81 .

[13] A. P. Corfield, N. Myerscough, Meth. Mol. Biol. 2000, 125,403 .

[14] N. Asano, R. J. Nash, R. J. Molyneux, G. W. J. Fleet, Tetrahedron: Asymm. 2000, 11, 1645.

[15] S. Hakamori, Proc. Natl. Acad. Sci. USA 2002, 99, 10231.

[16] D. Ayude, J. Fernandez-Rodriguez, F. J. Rodriguez-Berrocal, V. S. Martinez-Zorzano, A. de Carlos, E. Gil, M. Paez de la Cadena, Oncology 2000, 59, 310 .

[17] C. Dusseau, G. I. Murray, R. A. Keenan, T. O'Kelly, H. E. Krokan, H. L. McLeod, Int. J. Oncol. 2001, 18, 393.

[18] C. Franci, G. Egea, R. Arribas, A. J. Reuser, F. X. Real, Biochem. J. 1996, 314, 33.

[19] E. Gil-Martin, S. Gil-Seijo, C. Nieto-Novoa, A. Fernandez-Briera, Int. J. Biochem. Cell Biol. 1997, 28, 651 .

[20] E. Gil-Martin, F. J. Rodriguez-Berrocal, M. Paez de la Cadena, A. Fernandez-Briera, Oncology 1999, 56, 142.
[21] Y. Kakugawa, T. Wada, K. Yamaguchi, H. Yamanami, K. Ouchi, I. Sato, T. Miyagi, Proc. Natl. Acad. Sci. USA 2002, 99, 10718.

[22] T. Kato, Y. Wang, K. Yamaguchi, C. M. Milner, R. Shineda, S. Satomi, T. Miyagi, Int. J. Cancer 2001, 92, 797 .

[23] A.L.Reddi,K.Sankaranarayanan,H.S.Arulraj,N Devaraj, H. Devaraj, Cancer Lett. 2000, 158, 61.

[24] C. Slawson, J. Pidala, R. Potter, Biochim. Biophys. Acta 2001, 1537, 147.

[25] B. Sperker, U. Werner, T. E. Murdter, C. Tekkaya, P. Fritz, R. Wacke, U. Adam, M. Gerken, B. Drewelow, H. K. Kroemer, NaunynSchmiedbergs Arch. Pharm. 2000, 362, 110.

[26] J. M. Van den Elsen, D. A. Kuntz, D. R. Rose, EMBO J. 2001, 20, 3008.

[27] I. Vlodavsky, Y. Friedmann, M. Elkin, H. Aingorn, R. Atzmon, R. Ishai-Micaeli, M. Bita, O. Pappo, T. Peretz, I. Michal, L. Spector, I Pecker, Nat. Med. 1999, 5, 793.

[28] B. Winchester, Glycobiology 2005, 15, 1R.

[29] N. G. Beratis, A. Kaperonis, M. I. Eliopoulou, G. Kourounis, V. A. Tzingounis, J. Cancer Res. Clin. Oncol. 2005, 131, 371 .

[30] X. Wang, S. W. Tsao, Y. C. Wong, A. L. Cheung, Curr. Cancer Drug Targets 2003, 3, 153 .

[31] H. Cheng, X. Cao, M. Xian, L. Fang, T. B. Cai, J. J. Ji, J. B. Tunac, D. Sun, P. G. Wang, J. Med. Chem. 2005, 48, 845 .

[32] A. Vasella, G. J. Davies, M. Böhm, Curr. Op. Struct. Biol. 2002, 6, 619.

[33] P. F. Daniel, B. Winchester, C. D. Warren, Glycobiology 1994, 4, 551.

[34] T. Beccari, S. Stinchi, A. Orlacchio, Bioscience Rep. 1999, 19, 157.

[35] P. Wielgat, U. Walczuk, S. Szajda, M. Bien, L. Zimmoch, Z. Mariak, K. Zwier, J. Neurooncol. 2006, 80, 243.
[36] W. Yue, Y. L. Jin, G. X. Shi, Y. Liu, Y. Gao, Y Zhao, L. Zhu, Int. J. Cancer 2004, 108, 157.

[37] C. Rabouille, D. A. Kuntz, A. Lockyer, R. Watson, T. Signorelli, D. R. Rose, J. M. van den Heuvel, D. B. Roberts, J. Cell. Sci. 1999, 112 , 3319.

[38] J. M. van den Elsen, D. A. Kuntz, D. R. Rose, EMBO J. 2001, 20, 3008

[39] D. A. Kuntz, A. Ghavami, B. D. Johnston, B. M. Pinto, D. R. Rose, Tetrahedron: Asymm. 2005, 16,25 .

[40] S. Numao, D. A. Kuntz, S. G. Withers, D. R. Rose, J. Biol. Chem. 2003, 278, 48074.

[41] D. R. Rose, D. A. Kuntz, J. M. van den Elsen, US Pat. Appl. Pub., 2002, US 2002172670.

[42] S. Howard, S. He, S. G. Withers, J. Biol. Chem. 1998, 273, 2067.

[43] T. K. Yeo, K. T. Yeo, J. B. Parent, K. Olden, $J$. Biol. Chem. 1985, 260, 2565.

[44] M. J. Humphries, K. Matsumoto, S. L.White, K. Olden, Proc. Natl. Acad. Sci. USA 1986, 83, 1752.

[45] K. Olden, P. Breton, K. Grzegorzewski, Y. Yasuda, B. L. Gause, O. A. Oredipe, S. A. Newton, S. L. White, Pharmac. Ther. 1991, 50, 285.

[46] P. E. Goss, M. A. Baker, J. P. Carver, J. W Dennis, Clin. Cancer Res. 1995, 1, 935.

[47] P. E. Goss, C. L. Reid, D. Bailey, J. W. Dennis, Clin. Cancer Res. 1997, 3, 1077.

[48] M. Przybylo, A. Litynska, E. Pochec, Biochimie 2005, 87, 133

[49] W. H. Pearson, L. Guo, Tetrahedron Lett. 2001, $42,8267$.

[50] W. H. Pearson, E. J. Hembre, Tetrahedron Lett. 2001, 42, 8273 .

[51] S. Gerber-Lemaire, F. Popowycz, E. RodriguezGarcia, A. T. Carmona Asenjo, I. Robina, P. Vogel, ChemBioChem. 2002, 3, 466.

[52] F. Popowycz, S. Gerber-Lemaire, E. RodríguezGarcía, C. Schütz, P. Vogel, Helv. Chim. Acta 2003, 86, 1914.

[53] F. Popowycz, S. Gerber-Lemaire, C. Schütz, P. Vogel, Helv. Chim. Acta 2004, 87, 800.

[54] P. Englebienne, H. Fiaux, D. A. Kuntz, C. R. Corbeil, S. Gerber-Lemaire, D. R. Rose, N. Moitessier, PROTEINS 2007, 69, 160.

[55] H. Fiaux, D. A. Kuntz, D. Hoffman, R. C. Janzer, S. Gerber-Lemaire, D. R. Rose, L. Juillerat-Jeanneret, Bioorg. Med. Chem. 2008, 16, 7337.

[56] A. C. Dieserens, N. de Tribolet, A. MartinAchard, A. C. Gaide, J. F. Schnegg, S. Carrel, Acta Neuropathol. 1981, 53, 21.

[57] H. Fiaux, F. Popowycz, S. Favre, C. Schütz, P. Vogel, S. Gerber-Lemaire, L. JuilleratJeanneret, J. Med. Chem. 2005, 48, 4237.

[58] H. Fiaux, C. Schütz, P. Vogel, L. JuilleratJeanneret, S. Gerber-Lemaire, Chimia 2006, 60 , 185.

[59] S. Favre, H. Fiaux, C. Schütz, P. Vogel, L. Juillerat-Jeanneret, S. Gerber-Lemaire, Heterocycles 2006, 69, 179.

[60] S. Gerber-Lemaire, L. Juillerat-Jeanneret, MiniRev. Med. Chem. 2006, 6, 1043. 
Scientific Forum 2010

Von Nylon

\section{zu Nanomaterialien}

Die Zukunft der Polymere

Messe Basel, Halle 1- Saal Luzern (1. Stock)

\section{September} Schülertag

\section{2. - 23. September} Scientific Conference

24. September Berufstag für Studenten
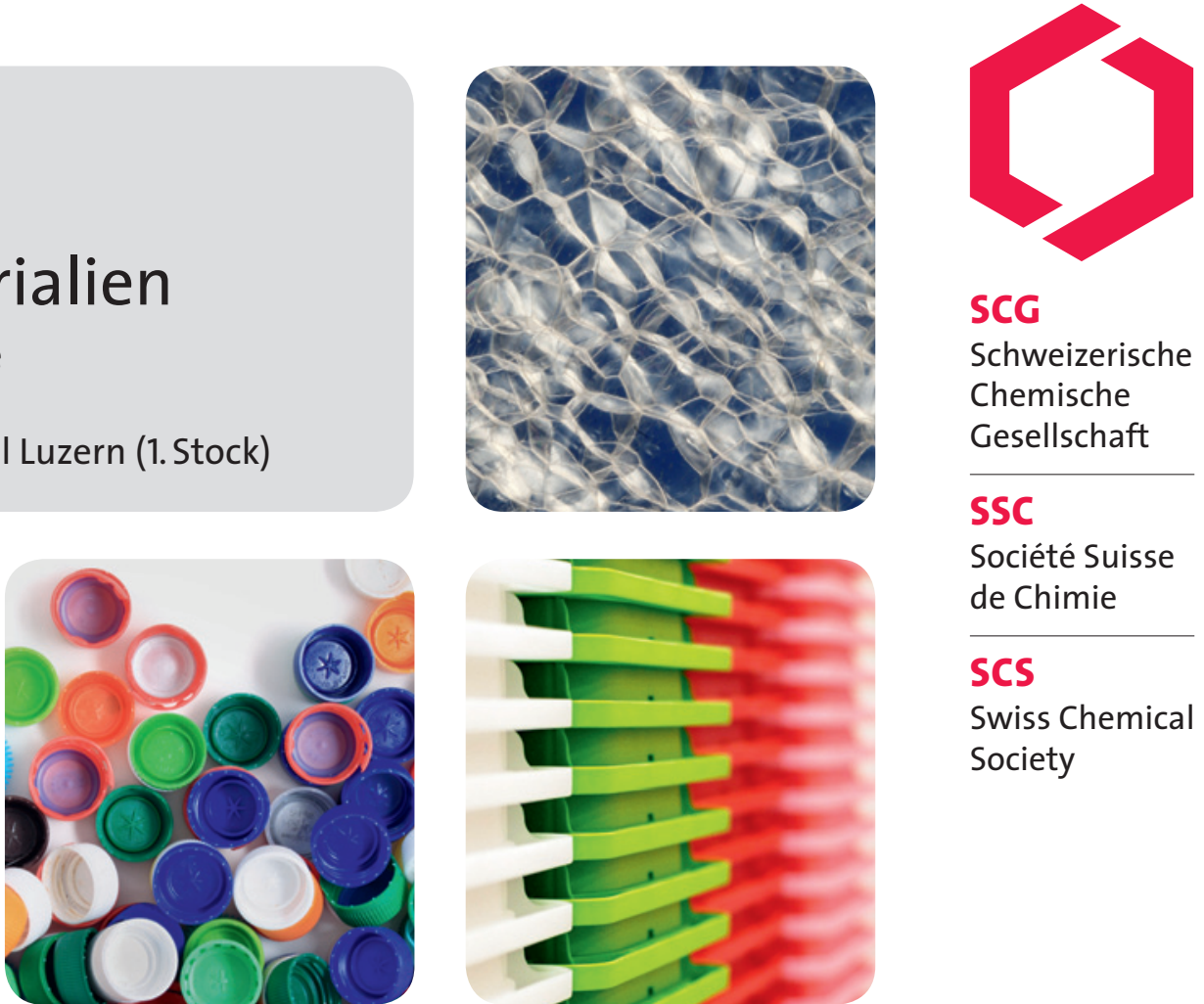

SCG

Schweizerische

Chemische

Gesellschaft

\section{SSC}

Société Suisse de Chimie

SCS

Swiss Chemical Society

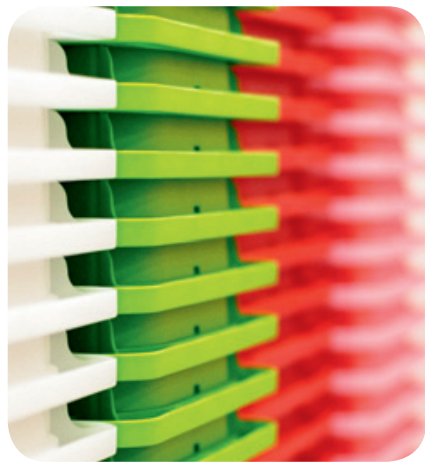

Tagespartner

Verein Schweizerischer Naturwissenschafts-

lehrerinnen und -lehrer
Dienstag, 21. September 2010 | Schülertag

Polymere im täglichen Leben

$\begin{array}{ll}\text { 9:30 } & \text { Begrüssung } \\ & \text { Prof. Peter Kündig, SCG-Präsident }\end{array}$

9:40 «Polymere für Knochen und Bildschirme: Was kleinste Partikel aus Plastik machen können ...» Prof. Wendelin Stark, ETH Zürich

10:05 «Medizinische Polymere - von Schläuchen und neuen Organen» Dr. Katharina Maniura, Empa

10:30 Live-Vorführung von Experimenten

10:50 Pause

11:20 Vorstellung von Maturaarbeiten Steve Clerc, Neuchâtel, «Les cordes dynamiques d'escalade: sécurité réelle ou psychologique?» Andreas Frutiger, Hilterfingen: «Fixierung und Reduktion von atmosphärischem $\mathrm{CO}_{2}$ mit Wasserstoff zu kurzkettigen Kohlenwasserstoffen"

11:50 Diskussion: «Alles Plastik, oder was?» Prof. Wendelin Stark, ETH Zürich

Dr. Katharina Maniura, Empa

Dr. Urs Klemm, Konsumentenforum

Fragen aus dem Publikum

Gesprächsleitung: Helen Issler

12:30 Imbiss (gratis)

Nachmittag: Besuch der Messe ILMAC, mit Wettbewerb (gratis, fakultativ)

\section{Partner \\ ILMAC"}

Kindly sponsored by

\section{Clariant}

-BASF 
Materials and Analytics

\begin{tabular}{|c|c|}
\hline 9:30 & $\begin{array}{l}\text { Welcome } \\
\text { Peter Kündig, SCS President }\end{array}$ \\
\hline 9:35 & $\begin{array}{l}\text { «Macromolecular Engineering for Functional } \\
\text { Nanostructured Materials» } \\
\text { Krzysztof Matyjaszewski, Carnegie Mellon University, USA }\end{array}$ \\
\hline 10:15 & $\begin{array}{l}\text { "Mass Spectrometry of Polymers with Special } \\
\text { Emphasis on MALDI» } \\
\text { Steffen Weidner, Bundesanstalt für Materialforschung } \\
\text { und -prüfung, Germany }\end{array}$ \\
\hline 10:50 & Coffee Break \\
\hline $11: 20$ & $\begin{array}{l}\text { "Novel Photoinitiators and Photopolymers for } \\
\text { Applications in Electronics" } \\
\text { Tobias Hintermann, BASF Schweiz }\end{array}$ \\
\hline $11: 55$ & $\begin{array}{l}\text { «Functional Nanomaterials: From Nanotoxicology to } \\
\text { Medical and Industrial Applications» } \\
\text { Wendelin Stark, ETH Zurich }\end{array}$ \\
\hline $12: 30$ & End of Conference Day One \\
\hline
\end{tabular}

Thursday, 23 September 2010 | Scientific Conference

Der Eintritt ist für alle Veranstaltungen kostenlos. Free admission, no registration.

Anmeldung von Gruppen erwünscht (weber@scg.ch).

Das Scientific Forum ist Partner der ILMAC und Teil der Basel Life Sciences Week 2010.

Weitere Veranstalter sind MipTec, BioValley und das Friedrich Miescher Institut.

www.basellifesciencesweek.ch www.scg.ch
Biological and Medical Applications

9:30 Welcome Paul Gilgen, President of the Organising Committee

9:35 «Biofunctional Processing and 3D Bioplotting of Biomaterials" Rolf Mülhaupt, University of Freiburg, Germany

10:15 «Delivery of Anticancer Agents by Liposomes: Nanomedicine in Action"

Alberto A. Gabizon, Shaare Zedek Medical Center and Hebrew University, Israel

\begin{tabular}{cl}
$10: 50$ & Coffee Break \\
\hline $11: 20$ & $\begin{array}{l}\text { «Biopolymers - Simply Natural!» } \\
\text { Linda Thöny-Meyer, Empa St. Gallen }\end{array}$ \\
$11: 55$ & $\begin{array}{l}\text { «Synthetic Biomembranes» } \\
\text { Wolfgang Meier, University of Basel }\end{array}$ \\
$12: 30$ & End of Conference Day Two
\end{tabular}

Chairman: Jürgen Vogt, Swiss Chemical Society

Freitag, 24. September 2010 | Berufstag

Berufsbilder und Firmenporträts aus der Polymerbranche

Tagespartner

\begin{aligned} & 9:30 $\begin{array}{l}\text { Begrüssung } \\ \text { Paul Gilgen, Präsident der ILMAC-Fachkommission der SCG }\end{array} \\ &$ 9:40 $\begin{array}{l}\text { Einführung } \\ \text { Jean-Nicolas Aebischer, Hochschule für Technik und } \\ \\ \text { Architektur Freiburg }\end{array} \\ &$ 9:50 Philip Nising, Sulzer Chemtech \\ & 10:10 Martin Vollmer, Clariant International \\ & 10:30 Bettina Steinmann, 3D Systems \\ & \hline 10:50 Pause \\ & \hline\end{aligned}

11:20 Christian Quellet, Givaudan Schweiz

11:40 Konrad Grob, Kantonales Labor Zürich

12:00 Thorsten Klein, Postnova Analytics

12:30 Ende des Programms

Moderator: Jean-Nicolas Aebischer, Hochschule für Technik und Architektur Freiburg

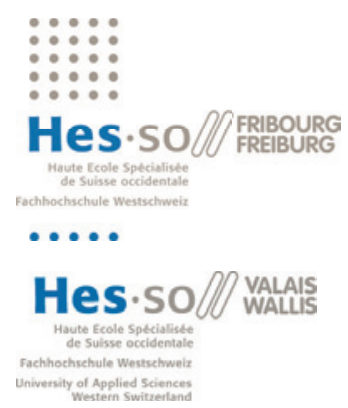

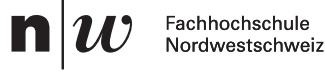

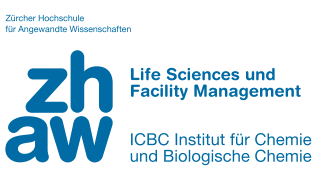




\section{Wednesday, 22 September 2010}

\section{Materials and Analytics}

\section{Macromolecular Engineering for Functional Nanostructured Materials}

\section{Krzysztof Matyjaszewski}

Center for Macromolecular Engineering, Department of Chemistry, Carnegie Mellon University, USA

Copper-based ATRP (atom transfer radical polymerization) catalytic systems with polydentate nitrogen ligands belong to the mostefficient controlled/living radical polymerization systems. ${ }^{[1,2]}$ Recently, by applying new initiating/catalytic systems, $\mathrm{Cu}$ level in ATRP was reduced to a few ppm. ${ }^{[3]}$

ATRP of acrylates, methacrylates, styrenes, acrylamides, acrylonitrile and many other vinyl monomers provides polymers with molecular weights in a large range $200<\mathrm{M}_{n}<20,000,000$ and with low polydispersities. Polymers can be formed quantitatively in bulk, in solution and in dispersed media. Block, graft, star, hyperbranched, gradient and periodic copolymers, molecular brushes and various hybrid materials as well as bioconjugates have been prepared..2] The (co)polymers made by CRP have many potential applications as components of advanced materials such as coatings, elastomers, adhesives, surfactants, dispersants, lubricants, additives, but also as specialty materials in biomedical and electronic areas and will affect the market of $\sim \$ 20$ billion/year. Examples of design, synthesis, characterization and applications of nanostructured multicomponent polymeric materials prepared via CRP will be presented.[4]

[1] 'Handbook of Radical Polymerization', Eds. K. Matyjaszewski, T. P. Davis, Wiley, Hoboken, 2002

[2] J. S. Wang, K. Matyjaszewski, J. Am. Chem. Soc. 1995, 117, 5614; K. Matyjaszewski, J. Xia. Chem. Rev. 2001, 101, 2921; K. Matyjaszewski et al., US 5,763,548; US 5,789,487; US 5,807,937; US 5,945,491.

[3] K. Matyjaszewski, W. Jakubowski, K. Min, W. Tang, J. Huang, W. A. Braunecker, N. V. Tsarevsky, Proc. Nat. Acad. Sci. 2006, 103, 15309; W. Jakubowski, K. Matyjaszewski, Angew. Chem. Int. Ed. 2006, 45, 4482; K. Min, H. Gao, K. Matyjaszewski, J. Am. Chem. Soc. 2006, 128, 10521

[4] K. Matyjaszewski, J. Spanswick, Materials Today 2005, 8, 26; K. Matyjaszewski, Y. Gnanou, L. Leibler, 'Macromolecular Engineering', Wiley-VCH, Weinheim, 2007; K. Matyjaszewski, N. V. Tsarevsky, Nature Chemistry 2009, 1, 276

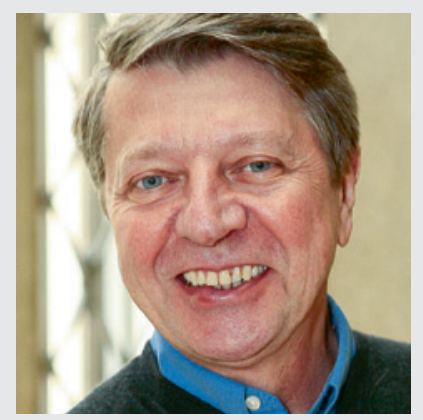

\section{Krzysztof Matyjaszewski} (PhD, 1976 Polish Academy of Sciences) is J. C. Warner University Professor of Natural Sciences and director of Center for Macromolecular Engineering at Carnegie Mellon University. His main research interests include controlled/ living radical polymerization, catalysis, environmental chemistry, and synthesis of advanced materials for optoelectronic and biomedical applications. He has co-authored over 600 publications, including 14 books and over 30 US and 100 international patents. His first paper and review on ATRP have been cited more than 2000 times each and his citation record $(>37,000)$ ranked among top 10 scientists in all fields of chemistry worldwide in 2004-2010. Matyjaszewski is a member of Polish Academy of Sciences and US National Academy of Engineering. He received honorary de- grees from University of Ghent, Belgium (2002), Russian Academy of Sciences (2006), Lodz Polytechnic, Poland (2007), University of Athens, Greece (2008) and l'Institut Polytechnique, Toulouse, France (2010). He developed atom transfer radical polymerization (ATRP), which has been commercialized in US, Europe and in Japan. Over 40 companies have been members of ATRP and CRP Consortia at $\mathrm{CMU}$ with ten signed commercial licenses.

\section{Mass Spectrometry of Polymers with Special Emphasis on MALDI}

\section{Steffen M. Weidner}

Federal Institute for Materials Research and Testing (BAM), Berlin, Germany

Since its introduction soft ionization methods like MALDIand ESI-TOF mass spectrometry have become indispensable tools for polymer characterization. For the first time molecular masses, mass distributions and chemical functionalities could be simultaneously obtained. Thus, MALDI and ESI-TOF MS are especially advantageous for the control of polymerizations, the determination of polymer modifications and in the analysis of degradation products. The combination with different separation methods will be presented, which can be useful to overcome drawbacks of mass spectrometry, and to achieve a characterization of even complex polymer and copolymer systems. Several examples of a comprehensive LC-MALDI analysis of several important classes of polymers (e.g. polyamides, polyesters, EO-PO copolymers) will be presented, demonstrating the potential of this coupling.

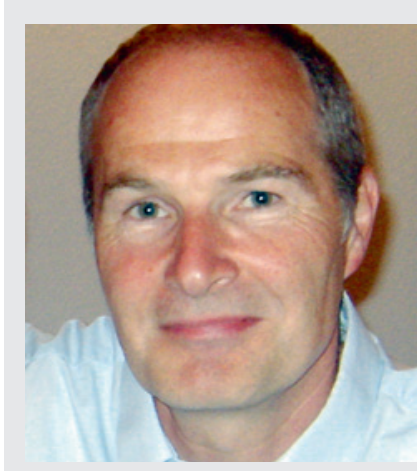

Steffen Michael Weidner received his $\mathrm{PhD}$ in Macromolecular Chemistry at the Technical University Berlin in 1996. Since March 2000, he is head of the working group 'Analysis of Polymers' at the Bundesanstalt für Materialforschung und -prüfung (BAM), the German Federal Institute for Materials Research and Testing in Berlin. He is a leading expert in using Matrix-assisted Laser Desorption/Ionization (MALDI) technology for analysis and characterization of polymers. He is the author of a high number of scientific papers and book chapters and member of the German and the American Society for Mass Spectrometry.

\section{Novel Photoinitiators and Photopolymers for Applications in Electronics}

\section{Tobias Hintermann}

Performance Chemicals Research BASF Schweiz AG, Basel, Switzerland

The electronic industry is an extremely fast developing and highly innovative sector of today's industry. Because of high competitiveness, it is driven by the constant demand for new devices 
with better performance (smaller size, reduced weight, improved energy efficiency) and new applications. The design of new devices is accompanied by a strong need for reduction of production costs for older generations. The first trend is facilitated by miniaturization of electronic components such as transistors and microchips, and the development of new technologies (e.g. OLED and e-paper displays, batteries with higher energy density). On the other hand costs can be lowered by an increase in production efficiency through improved processes, increased substrate size, and reduced size of components.

Fast cure on demand is advantageous to many manufacturing processes in the electronic industry. Examples of applications are the encapsulation and sealing of sensitive electronic components, displays and solar cells, adhesives for lamination and assembly of electronic parts and devices, and curing of dielectrics and insulating layers in printed electronics. Optical micro-lithography processes are of particular importance because they permit a fast and precise production of two- and three-dimensional structures by applying patterning techniques to photosensitive layers, using image-wise exposure in connection with layer-wise build-up technology to create electronic functionalities. Some of the most important application fields for micro-photolithography in the electronic industry are in the manufacturing of display panels (thin film transistors, color filter, black matrix, photo-spacers, insulating layers), semiconductors (i.e. integrated circuits, microprocessors, DRAM and flash memory), and microelectromechanical systems (MEMS).

Advancements in optical micro-lithography tools, processes and particularly photosensitive materials are critical for the continued advancement of microelectronic devices. Today, ArF-excimer laser nano-lithography generates precise patterns with a resolution of $<40 \mathrm{~nm}$ with chemically amplified photoresists comprising highly optimized photo acid generator (PAG) as photoactive component. In the last few years BASF has developed a series of Irgacure ${ }^{\circledR}$ PAGs for different lithographic requirements and exposure wavelengths; i-line (365 nm), KrF (248 nm), ArF (193 nm). Today's ArF PAG technology can be extended to meet the demand of future EUV (13.5 nm) lithography.

Significant progress of the manufacturing technology for liquid crystal displays was enabled by BASF's innovative photoinitiator Irgacure $^{\circledR}$ OXE02. This extremely sensitive photoinitiator is used to pattern an environmentally friendly organic resin black matrix (RBM) which separates the red, blue, and green sub-pixels to provide improved contrast in LCD-TVs. The new technology allowed the replacement of the formerly used environmentally problematic chromium metal in this application, and at the same time improves the manufacturing process by eliminating numerous technical issues potentially arising through the use of the traditional method.

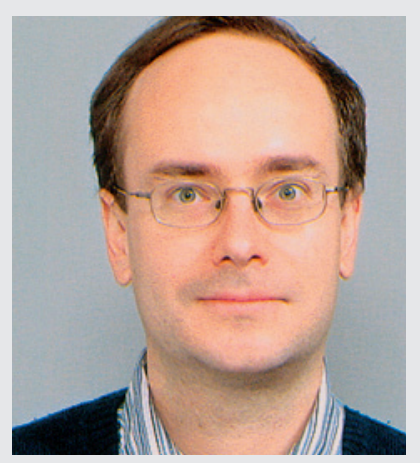

Tobias Hintermann received his $\mathrm{PhD}$ from ETH Zürich and then moved to Harvard University for a postdoc before joining Ciba SC in 2000. In 2003 he moved to the Ciba research center for electronic materials in Amagasaki, Japan, working on several topics related to microelectronics. Returning to Basel he became head of the photoinitiators research group in the Research Center for Polymerization \& Curing Agents in 2008, and after integration of Ciba into BASF he is now part of BASF Performance Chemicals Research, Basel. His current interest spans the field of photoinitiators, photoacid generators, and photolatent catalysts. He is the author of more than 30 scientific papers and patents.

\section{Functional Nanomaterials: From Nanotoxicology to Medical and Industrial Applications}

\section{Wendelin J. Stark}

\section{Functional Materials Laboratory, ETH Zürich, Switzerland}

The properties of nanoparticles are between solids and small molecules. We may even compare them in parts with polymers, where an arrangement of monomers determines the polymer's fate. In a particle, the 'monomers' are clustered differently (amorphous or crystalline). Visionary concepts have spread from a fundamental understanding of small particles. But novel and rather down-toearth applications are available already today: Especially magnetic nanoparticles show the way for the accelerated transfection of vectors into cells ${ }^{[1]}$ or in vivo extraction of noxious compounds. ${ }^{[2]}$ Artificial muscles or improved materials for implants comprising nanoparticulate materials might be implemented. ${ }^{[3]}$ Amorphous calcium phosphates and bioactive nanoglass are under preclinical investigation for bone healing or to fight osteoporosis as toothpaste-like injectable bone cement, which hardens within minutes inside a living organism. ${ }^{[4]}$ Nano-silver is well-known for its antimicrobial properties and consequently will be found in even more industrial products than already today. ${ }^{[5]}$

Nanoparticles interact with cells in unprecedented ways which affect public perception and may result in product risks (e.g. Trojan-horse type toxin uptake).[6] Unraveling non-traditional mechanisms, however, may result in improved or even completely new medical treatment concepts, considering that the wealth of pharmaceuticals available today has largely been fueled by such understanding of molecules within biological systems. In fact, the majority of broadly used medications have been originally identified on the basis of a toxic effect. These and other implementations of nanomaterials in medical and technical applications will be presented.

[1] C. Plank, U. Schillinger, F. Scherer, C. Bergemann, J.-S. Remy, F. Krötz, M Anton, J. Lausier, J. Rosenecker, Biol. Chem. 2003, 384, 737.

[2] I. K. Herrmann, M. Urner, F. M. Koehler, M. Hasler, B. Roth-Z'Graggen, R. N. Grass, U. Ziegler, B. Beck-Schimmer, W. J. Stark, Small 2006, 10, 1388

[3] R. Fuhrer, E. K. Athanassiou, N. A. Luechinger, W. J. Stark, Small, 2009, 5, 383.

[4] M. Bohner, T. J. Brunner, W. J. Stark, J. Mater. Chem. 2008, 18, 5669.

[5] T. Waltimo, T. J. Brunner, M. Vollenweider, W. J. Stark, M. Zehnder, J. Dent. Res. 2007, 86, 754.

[6] L. K. Limbach, P. Wick, P. Manser, R. N. Grass, A. Bruinink, W. J. Stark, Environ. Sci. \& Techn. 2007, 41, 4158.

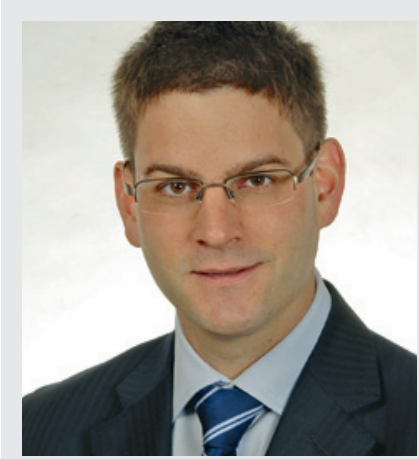

Wendelin J. Stark (1976) received his Master in Chemistry in 2000 followed by a $\mathrm{PhD}$ in Mechanical Engineering in 2002 from ETH Zurich. He founded the Functional Materials Laboratory at the Department of Chemistry and Applied Biosciences at ETH Zürich in 2004. Applicationoriented research at the interface of chemistry with material science and medicine has resulted in several commercialized products and two implant materials currently undergoing preclinical investigations. Since 2004, seven PhDs were finished with an average duration of three years. Since 2007, he has published about 15-20 research articles per year in top peerreviewed journals and is currently author of about 100 papers 
and 16 patents as well as numerous (over 150) reviewed proceedings and presentations at leading conferences in chemical and medical engineering. The Functional Materials Laboratory has acquired prominent industrial partners with a long-term commitment, and currently assists a product development in a Global-100 company. A European Fortune-200 company is currently implementing a process developed in Professor Stark's laboratories. In 2007, a spin-off company (Turbobeads) was founded out of his laboratory to commercialize magnetic molecule tags and accelerated medical diagnostics. In summer 2008, a second spin-off company (Nanograde) has been launched from Professor Stark's research group.

\section{Thursday, 23 September 2010}

\section{Biological and Medical Applications}

\section{Biofunctional Processing and 3D Bioplotting of Biomaterials}

\section{Rolf Mülhaupt}

Freiburg Materials Research Center (FMF), University of Freiburg, Freiburg, Germany

Biofunctional processing of biomaterials represents an important challenge in regenerative medicine with applications ranging from tissue repair and drug release to organ printing. The ultimate goal is to import data from computer tomography or X-ray into computer assisted design (CAD) in order to design and fabricate biofunctional tissue meeting the special demands of individual patients. The majority of conventional polymer processing technologies such as molding and casting fail to process bioactive components because they require either high temperatures or rather toxic resins. The computer-guided mold-free layer-by-layer fabrication, known as Rapid Prototyping (RP), and originally developed for concept modelling in automotive industry, offers attractive opportunities for biofunctional processing. Selective laser sintering and stereolithography are used to fabricate implants and hearing aids, but do not tolerate bioactive components. Today 3D inkjet printing and $3 \mathrm{D}$ bioplotting ${ }^{\mathrm{TM}}$ have been developed to process aqueous systems containing cells and biopolymers. The $3 \mathrm{D}$ printing inks require very low viscosity. Thermoreversible gels were employed as printing inks for cell printing. In contrast, the 3D Bioplotting process, developed at the Freiburg Materials Research Center in close collaboration with EnvisionTec and Prof. Dr. R. Schmelzeisen at the University Hospital, is extraordinarily versatile with respect to the choice of materials, and can process solutions, pastes, melts, dispersions exhibiting low and very high viscosities. Strands and microdots are dispensed via a 3D movable nozzle. A wide range of polymer solutions (PLA, PE, collagen, cellulose), cements, and also reactive resins (PUR, silicones, acrylics, fibrinogen) can be processed. In contrast to many other technologies, no temporary support structures are required. Plotting in liquid media and matching the densities of the materials and the plotting medium enables buoyancy compensation of gravity. Soldification involves either physical crosslinking by cooling below glass and melting temperature, and also chemical crosslinking by means of ionomer formation and other chemical reactions. Reactive plotting (fibrin, alginates) afforded fabrication of structured hydrogel scaffolds. Multiple-3D dispensing enables fabrication of hybrid materials with $3 \mathrm{D}$ positioning of components. In a recent advance hydrogel precursors were modified to enable 3D plotting of osteoblast cell suspensions which form functional tissue. The 3D scaffolds can also be equipped with other biological functions such as controlled drug release. Ceramic and hydrogel scaffolds have been used in vivo for bone repair.

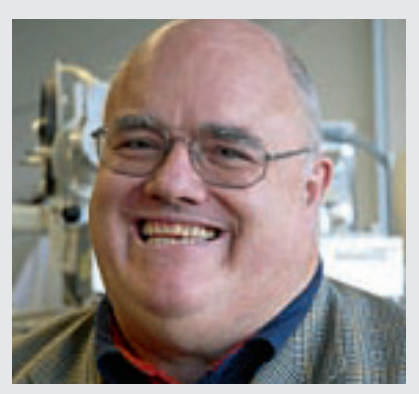

Rolf Mülhaupt is professor of macromolecular chemistry and director of the Freiburg Materials Research Center at the University of Freiburg, Germany. He studied chemistry in Freiburg and received his $\mathrm{PhD}$ in 1981 at ETH Zürich. After industrial research at $\mathrm{Du}$ Pont in Wilmington/Delaware (1981-1985) and Ciba in Marly/CH (1985-1989), he joined the University of Freiburg in 1989. His research includes polymer chemistry, catalysis, multiphase polymers, nanocomposites, functional processing, and specialty polymers and additives. He received the Piero Pino gold medal of the Italian Chemical Society (2004) and the Hermann Staudinger Prize of the German Chemical Society (2009). Since 2000 he has been a member of the Heidelberg Academy of Sciences.

\section{Delivery of Anticancer Agents by Liposomes: Nanomedicine in Action}

\section{Alberto A. Gabizon}

Shaare Zedek Medical Center and Hebrew University-School of Medicine, Jerusalem, Israel

Despite the advent of new molecular targeted therapies for cancer, most of the currently used anti-tumor agents have problematic toxicities compromising efficacy, and often resulting in life-threatening events. Liposomes can provide effective control of the release rate and of the tissue distribution of many of these agents. These pharmacokinetic changes often have a major pharmacodynamic impact with attenuation of toxic effects and protection of sensitive tissues from dangerous and unwanted drug exposure. Polyethylene-glycol (PEG) coating of liposomes results in inhibition of liposome uptake by the reticulo-endothelial system and significant prolongation of liposome residence time in the blood stream. A hallmark of these long-circulating liposomal drug carriers is their enhanced accumulation in tumors. The mechanism underlying this passive targeting effect is the phenomenon known as enhanced permeability and retention (EPR) which has been described in a broad variety of experimental tumor types, and appears also to be a relevant phenomenon in human cancer. Developments in drug loading technology have improved the efficiency and stability of drug entrapment in liposomes, particularly with regard to anthracyclines, vinca alkaloids, and camptothecin analogs. An example of a liposome formulation with demonstrated clinical added value is PEGylated liposomal doxorubicin, which has demonstrated clinically a favorable safety profile with an impressive reduction in cardiac toxicity and proven efficacy against various malignancies and can be considered as the first anti-cancer nanomedicine approved for clinical use. In summary, liposome-based systems offer a vast array of potential applications in the delivery of cancer chemotherapeutic agents which may result in a substantial improvement of the therapeutic index. Although liposomal doxorubicin has already found a place in routine clinical use, the potential of liposomal drug delivery remains so far under-exploited. 


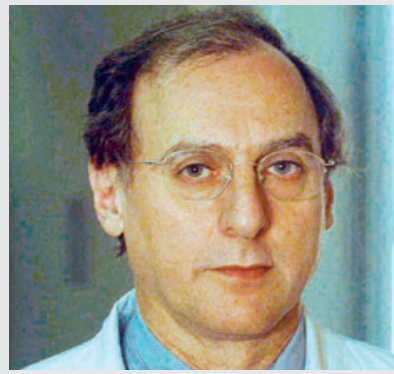

Alberto (Abraham) Gabizon (born 1951 in Tetuan, Morocco), received his medical degree at the School of Medicine in Granada, Spain, and his doctorate $(\mathrm{PhD})$ in Cell Biology from the Weizmann Institute of Science in Rehovot, Israel. He completed his residency in Oncology at the Hadassah Medical Center in Jerusalem, and obtained the Israeli board certification in Radiation and Medical Oncology in 1985. Between 1985-1988, he spent three years on a research fellowship at the Cancer Research Institute of the University of California in San Francisco, where he helped to develop a new generation of long-circulating liposomes known as Stealth liposomes which have greatly improved stability and selective accumulation in tumors. Dr. Gabizon returned to Israel in 1989 as Senior Staff Physician and Investigator at the Sharet Institute of Oncology of Hadassah Medical Center where he continued his research and clinical activity until 2001. In 2002, Dr. Gabizon was appointed Chairman of the Oncology Institute at Shaare Zedek Medical Center, and Professor of Oncology at the Hebrew University-Faculty of Medicine in Jerusalem, his current appointment. Dr. Gabizon has received the Spanish National Prize of Medical Graduation (1975), the Career Research Award (1989) and Professorship Award (2008) of the Israel Cancer Research Fund, the Hebrew University Kaye Innovation Award (1997) for the invention 'Liposomal Doxorubicin for Cancer Treatment', and most recently the Alec Bangham Life Time Achievement Award of the International Liposome Research Society. Dr. Gabizon's research contribution placed a central role in the development of PEGylated liposomal doxorubicin (known as Doxil or Caelyx), a unique anticancer formulation extensively used in the clinic with important pharmacologic and safety advantages over conventional chemotherapy. Dr. Gabizon is active in the medical oncology field in early clinical trials, and in preclinical pharmacology research with special emphasis on applications of liposomes in drug delivery, targeting of drugs, and experimental cancer therapy, and has published around 120 original articles and specialized book chapters. Dr. Gabizon is a resident of Jerusalem, married and father of four children.

\section{Biopolymers - Simply Natural?!}

\section{Linda Thöny-Meyer}

Empa

Laboratory for Biomaterials, St. Gallen, Switzerland

The term biomaterial is often used explicitly in the context of medical applications, where biodegradability and biocompatibility play a critical role. In this presentation I will discuss examples of various classes of biopolymers with applications that are not exclusively related to a use in the body, i.e. for medical purposes. Such biopolymers span several families of substances, including polysaccharides, polyester, polyphenols, polynucleotides, and polypeptides. The huge reservoir of Nature's biopolymers with remarkable characteristics can be expanded by man-made technologies, leading to novel combinations of polymers or their building blocks in bio-derived polymers.

The sector of industrial ('white') biotechnology includes the production and engineering of biopolymers. At Empa we focus not only on the engineering of biomaterials for special applications but also on synthesis and production of novel biomaterials. Cellulose makes up 50\% of the cell wall of plant cells where it provides stability and keeps the plants in shape. The Empa wood laboratory explores the production and application of nano-cellulose. By physical treatment natural cellulose fibers are broken down into nanofibrils which form networks of polymers with high surface area, which are rich in hydrophilic groups. The advantages of such nanofibrils in materials are their high stability, transparency, good barrier functions and their reactivity allowing chemical modification.

In the laboratory for biomaterials we change the characteristics of biopolymers in new combinations with additives in order to obtain material characteristics for special purposes, e.g. degradable materials in fields of textiles, packaging, agriculture and medicine. We also use biotechnology to produce polyesters and polypeptides from bacteria. Bacterial strains are engineered such that waste materials can be used for the production of cell mass. By applying special fermentation conditions we obtain high cell densities and improve yields. In addition we develop environmentally friendly procedures to isolate polyhydroxyalkanoate bioplastics in medical grade. The obtained material is used for medical but also biological applications. Enzymes involved in synthesis, degradation or conversion of biopolymers are cloned, produced and engineered in our laboratory. An example is tyrosinase, the key enzyme of melanin biosynthesis, which has further applications such as protein immobilization.

Biopolymers comprise polymeric materials that are either bio-based, i.e. made by natural processes from natural sources, or that can be degraded by natural processes. In times when petrochemical resources become more limited, or are regarded ecologically problematic, these sustainable materials are expected to become more and more important and economically competitive.

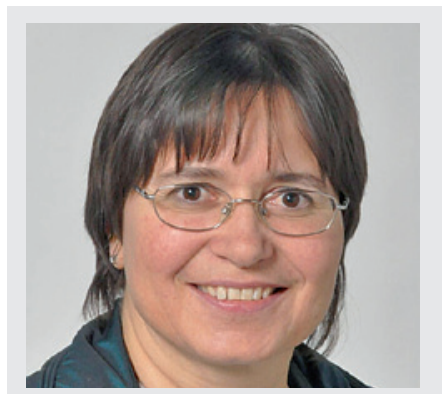

Linda Thöny-Meyer has been the head of the Laboratory for Biomaterials at Empa since 2006. She performs R\&D in the field of biopolymers and biocatalysis. She graduated 1988 at ETH Zürich with honors. After postdoctoral activities at Stanford University she habilitated in 1997 and became an assistant professor for Molecular Microbiology at the Institute of Microbiology, ETH Zürich. 2004-2006 she worked as a patent attorney for E. Blum \& Co in Zürich. For her research contributions she obtained several awards including the title of an honorary doctor from Lund University, Faculty of Sciences, where she also served in the Scientific Advisory Board.

\section{Synthetic Biomembranes}

\section{Wolfgang Meier and Nico Bruns}

Department of Chemistry of the University of Basel Basel, Switzerland

Similar to conventional lipids, suitable amphiphilic block copolymers may self-assemble in aqueous media to membranelike superstructures. The physical properties of these membranes can be controlled to a large degree via the chemical constitution, 
the molecular weight and the hydrophilic-to-hydrophobic block length ratio of these polymers. Compared to conventional low molar mass building blocks (e.g. lipids), membranes based on macromolecular self-assembly not only have the advantage of superior stability and toughness, but in addition offer numerous possibilities of tailoring physical, chemical and biological properties since many functions can be implemented simultaneously in one single macromolecule.

Moreover, other well-defined functions such as recognition, cooperativity, regulation, replication, and catalysis can be introduced by combining these superstructures with suitable functional groups from nature, e.g. by incorporation of integral membrane proteins into the biomimetic membranes. Recently, we used this concept to prepare polymer nanoreactors by encapsulating watersoluble enzymes inside the aqueous compartments of block copolymer vesicles. Channel proteins were used to selectively control the exchange of substrates and products with the environment. Immobilized polymer nanoreactors were used as chemically and mechanically stable, nanometer-sized compartments to follow folding/unfolding of single proteins and to monitor enzymatic reactions down to a single nanoreactor scale. Model reactions were used to demonstrate the potential of these structures for biosensing and the local production of bioactive compounds. In addition, these nanoreactors can be targeted to predefined cells. After cellular uptake, they retain their function over extended times inside the living cells, thus acting as a sort of artificial organelle. This opens new ways for controlled drug delivery and intracellular sensing.

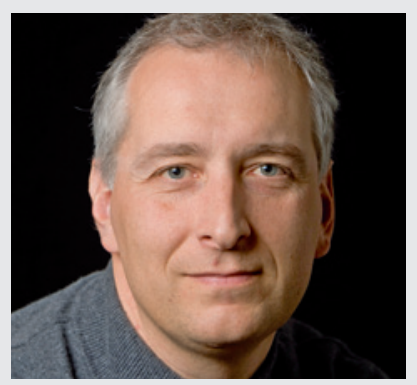

Wolfgang Meier studied Chemistry at the University of Freiburg and received his $\mathrm{PhD}$ degree in Macromolecular Chemistry in 1992. In 1996 he was appointed as lecturer in Physical Chemistry at the University of Basel where he received his 'Habilitation' in 1998. In 2001 he was appointed as professor at the International University of Bremen and since 2003 he is Professor of Chemistry at the University of Basel. He received several awards (Ruzicka-Prize, 2001; Hermann-Staudinger-Prize, 2006) for his research.

His main research interests are in the field of hierarchical selfassembly of functional polymers, and polymer-protein hybrid materials

Nico Bruns is currently a 'Habilitand' (research group leader) at the Department of Chemistry at the University of Basel. He studied Chemistry at the Universities of Freiburg and Edinburgh. He received his PhD in Macromolecular Chemistry in 2007. He then spent one and a half years as a postdoctoral researcher at the University of California, Berkeley, after which he came to Basel to establish his own line of research and his own research group. He received a scholarship from the German National Academic Foundation (Studienstiftung des deutschen Volkes), a Marie Curie Intra European Fellowship, as well as several awards, e.g. the Pfizer-Research Award for Young Scientists. His research interests include cage-like proteins as nanoreactors and functional nano-devices. He is also investigating polymer-protein hybrid materials and amphiphilic copolymer systems. 